\title{
Retraction: Recursive fury: conspiracist ideation in the blogosphere in response to research on conspiracist ideation
}

\section{Frontiers in Psychology Editorial Office *}

*Correspondence: psychology.editorial.office@frontiersin.org

\section{Approved by:}

Axel Cleeremans, Université Libre de Bruxelles, Belgium

A retraction of the Original Research Article:

Recursive fury: conspiracist ideation in the blogosphere in response to research on conspiracist ideation

by Lewandowsky, S., Cook, H., Oberauer, K., and Marriott, M. Front. Psychol. 4:73. doi: 10.3389/fpsyg.2013.00073

In the light of a small number of complaints received following publication of the original research article cited above, Frontiers carried out a detailed investigation of the academic, ethical, and legal aspects of the work. This investigation did not identify any issues with the academic and ethical aspects of the study. It did, however, determine that the legal context is insufficiently clear and therefore Frontiers wishes to retract the published article. The authors understand this decision, while they stand by their article and regret the limitations on academic freedom which can be caused by legal factors.

Received: 21 March 2014; accepted: 21 March 2014; published online: 27 March 2014.
Citation: Frontiers in Psychology Editorial Office (2014) Retraction: Recursive fury: conspiracist ideation in the blogosphere in response to research on conspiracist ideation. Front. Psychol. 5:293. doi: 10.3389/fpsyg. 2014.00293

This article was submitted to Personality Science and Individual Differences, a section of the journal Frontiers in Psychology.

Copyright (c) 2014 Frontiers in Psychology Editorial Office. This is an open-access article distributed under the terms of the Creative Commons Attribution License (CC BY). The use, distribution or reproduction in other forums is permitted, provided the original author(s) or licensor are credited and that the original publication in this journal is cited, in accordance with accepted academic practice. No use, distribution or reproduction is permitted which does not comply with these terms. 